\title{
Identification of Phosphorus Efficient Rice Cultivars under Low P Nutrition through Hydroponic based Screening
}

\author{
D.S. Kekulandara ${ }^{1 *}$, P.C.G. Bandaranayake ${ }^{2}$, D.N. Sirisena ${ }^{1}$, W.L.G. Samarasinghe ${ }^{3}$ and \\ L.D.B. Suriyagoda ${ }^{4}$
}

\author{
Postgraduate Institute of Agriculture \\ University of Peradeniya \\ Sri Lanka
}

\begin{abstract}
Phosphorus (P) is one of the major nutrients required by plants. A higher portion of $\mathrm{P}$ in lowland rice soils is found in unavailable forms due to fixation. Therefore, continuous application of $\mathrm{P}$ fertilizer to rice (Oryza sativa $\mathrm{L}$.) is needed to obtain a satisfactory yield. Identification and subsequent cultivation of high yielding rice varieties which can withstand low level of $\mathrm{P}$ is a better alternative to the continuous $\mathrm{P}$ application. The objective of this study was to categorize Sri Lankan rice varieties according to their response to $\mathrm{P}$ deficient conditions. Forty eight rice varieties including three old improved varieties and 45 new improved varieties were evaluated at deprived $(10 \mu \mathrm{M} \mathrm{P})$ and sufficient $(50 \mu \mathrm{M} \mathrm{P}) \mathrm{P}$ levels in a nutrient solution culture. Multiple plant traits; number of tillers, root and shoot dry weights and $\mathrm{P}$ content in shoot tissues were assessed at 52 days after planting. Rice variety Bg 94-1 gained higher biomass and P uptake (i.e. shoot P content- mg/plant). Simultaneously, At402 had lower biomass gain and shoot $\mathrm{P}$ content. Rice varieties were grouped into two distinct clusters based on their responses to $\mathrm{P}$ deficiency such as biomass gain, $\mathrm{P}$ uptake and number of tillers per plant. This study showed that At 405, Bg 94-1, At 307, Bg 304, Bg 300 and At 354 are promising rice varieties with higher response to low level of $\mathrm{P}$ supply.
\end{abstract}

Keywords: Deficiency, germplasm evaluation, phosphorus, screening, tolerance

\section{INTRODUCTION}

Rice is the most important food crop in Asia, and the food security mainly depends on the production of rice. As such rice cultivation plays a big role in Asia generating income directly and indirectly (Dawe, 2000). Increase in the rate of rice production shows a diminishing trend with urbanization, climate change and soil problems. Therefore, the increase in rice production should be obtained through increasing productivity of rice per unit area cultivated (Redfern $e t$ $a l ., 2012$ ). One solution for increasing production efficiency (i.e. productivity) in rice is through the development of higher-yielding and nutrient efficient varieties (Kush, 1995). Sixteen essential elements are required for proper growth of rice; mainly nitrogen $(\mathrm{N})$, phosphorus $(\mathrm{P})$ and potassium $(\mathrm{K})$ are supplied in rice fields as inorganic fertilizers in greater quantities (De Datta, 1981). Unavailability of adequate amount of $\mathrm{P}$ in soil, retarded plant

1 Rice Research \& Development Institute, Batalagoda, Ibbagamuwa, Sri Lanka

2 Agricultural Biotechnology Centre, Faculty of Agriculture, University of Peradeniya, Sri Lanka

3 Plant Genetic Resource Centre, Peradeniya, Sri Lanka

4 Department of Crop Science, Faculty of Agriculture, University of Peradeniya, Sri Lanka

* Corresponding author: deepthikasaman@gmail.com 
growth and development resulting significant yield losses (Dobermann and Fairhurst, 2000). Phosphorus requirement and acquisition are higher during the early growth stages (Vinod and Heuer, 2012).

Applied $\mathrm{P}$ is quickly converted to unavailable forms adhering to soil particles and can lead to deficiency in available $\mathrm{P}$ in soil. Also $\mathrm{P}$ deficiency in soil can occur due to the low $\mathrm{P}$ content of the parental material, low $\mathrm{pH}$ and soil with high P-fixing characteristics (Rose and Wissuwa, 2012). Phosphorus deficiency is one of the major limiting factors for crop production in highly weathered soils (Sanchez and Salinas, 1981). Some soil properties, such as soil pH, clay, Fe and $\mathrm{Al}$ contents are closely related to the $\mathrm{P}$ sorption capacity of the soils. Due to high $\mathrm{P}$ fixation capacity, a greater amount of external $\mathrm{P}$ should be applied to reach higher productivity (Yost et al., 1979). Excessive application of $\mathrm{P}$ fertilizers can cause $\mathrm{P}$ contamination of freshwater bodies. This triggers the eutrophication in freshwater systems (Tirado and Allsopp, 2012). Therefore, it is important to use a balance fertilizer for sustainable rice farming. Application of high amounts of $\mathrm{P}$ fertilizers for two seasons per year has increased the accumulation of $\mathrm{P}$ in Sri Lankan soils (Sirisena and Suriyagoda, 2018). Therefore, the most economical and environmental friendly alternative is to introduce rice varieties which perform well under low $\mathrm{P}$ conditions.

Rice varieties differ significantly in their $\mathrm{P}$ requirement under $\mathrm{P}$ deficient condition. To identify P efficient varieties shoot and root dry weight can be used as a criterion for screening (Fageria.1998). Kottearachchi et al. (2013) has reported that there is a significant difference in root length and shoot dry weight between rice varieties grown under low $\mathrm{P}$ hydroponic system although there was no such difference in high $\mathrm{P}$ supplied condition. Meanwhile, Aluvihare et al. (2015) has identified Bg94-1, Bg403 and At362 as P deficiency tolerant varieties. The aim of this work was to identify the variation in P deficiency tolerance in Sri Lankan rice varieties under controlled $\mathrm{P}$ levels in hydroponic nutrient medium, and thereby identify the best performing varieties having deficiency tolerance at vegetative stage.

\section{METHODOLOGY}

The experiment was conducted in a glasshouse at the Agricultural Biotechnology Center, University of Peradeniya, Sri Lanka. Minimum and maximum temperatures inside the glasshouse during this period were $26^{\circ} \mathrm{C}$ and $38^{\circ} \mathrm{C}$, respectively. Forty eight locally bred rice varieties, forty-five new improved and three old improved rice varieties under different maturity age groups were screened in Yoshida nutrient solution with low $(10 \mu \mathrm{M})$ and high $(50 \mu \mathrm{M}) \mathrm{P}$ concentrations (Table 1).

\section{Establishment and maintenance of plants}

Seeds were imbibed in water for $24 \mathrm{~h}$ and germinated. Seedlings were transferred in to plastic buckets filled with full strength Yoshida nutrient solution (Yoshida, 1976) supplemented with $50 \mu \mathrm{M}$ of P (optimal) or $10 \mu \mathrm{M}$ P (deprived) concentrations (Kekulandara et al., 2016). Sodium dihydrogen phosphate monohydrate $\left(\mathrm{NaH}_{2} \mathrm{PO}_{4} \cdot \mathrm{H}_{2} \mathrm{O}\right)$ was used as the $\mathrm{P}$ source. Six seedlings per bucket were maintained with equal spacing. The $\mathrm{pH}$ of the solution was maintained at 5.6 - 5.8 and it was replaced once a week. The experimental design was Complete Randomized Design with 3 replicates. 
Table 1. Rice varieties used for the study

\begin{tabular}{|c|c|c|c|}
\hline Variety & $\begin{array}{l}\text { Duration } \\
\text { (months) }\end{array}$ & Recommendation & Pedigree \\
\hline \multicolumn{4}{|c|}{ New Improved Varieties } \\
\hline $\mathrm{Bg} 250$ & $21 / 2$ & Drought/flood escaping & Farmer field selection \\
\hline $\mathrm{Bg} 300$ & 3 & General cultivation & Bg 367-7//IR 841/Bg 276-5 \\
\hline $\mathrm{Bg} 304$ & 3 & General cultivation & Co 10/IR 50//84-1587/Bg 731-2 \\
\hline $\mathrm{Bg} 305$ & 3 & General cultivation & Bg 1203/Bg 1492 \\
\hline $\mathrm{Bg} 310$ & 3 & Saline prone areas & Bg 300/Pokkali \\
\hline Bw272-6B & 3 & Low country wet zone & BW 259-3/BW 242-5-5 \\
\hline At303 & 3 & General cultivation & At $66-2 / \mathrm{Bg} 276-5$ \\
\hline At306 & 3 & General cultivation & OB 2273/At 05 \\
\hline At307 & 3 & General cultivation & Bg 2225-1/Bg 96-3298 \\
\hline At 308 & 3 & General cultivation & Bg 2225-1/Bg 2426-2 \\
\hline Bg366 & $31 / 2$ & General cultivation & Bg300/94-2236//Bg300/Bg304 \\
\hline $\mathrm{Bg} 352$ & $31 / 2$ & General cultivation & $\mathrm{Bg} 380 / \mathrm{Bg} \mathrm{367-4}$ \\
\hline Bg369 & $31 / 2$ & Saline prone areas & Bg 94-1/Nonabokra \\
\hline $\mathrm{Bg} 360$ & $31 / 2$ & General cultivation & 84-3346/IR36//Senerang \\
\hline $\mathrm{Bg} 357$ & $31 / 2$ & Island wide cultivation & $\begin{array}{l}\text { Bg797/Bg300//85-1580/ } \\
\text { Senerang M-17 }\end{array}$ \\
\hline $\mathrm{Bg} 358$ & $31 / 2$ & General cultivation & $\mathrm{Bg} 12-1 / \mathrm{Bg} 1492$ \\
\hline Bg94-1 & $31 / 2$ & General cultivation & IR 262/Ld66 \\
\hline Bw361 & $31 / 2$ & General cultivation & IR 36/Bw 267-3-11M \\
\hline Bg359 & $31 / 2$ & Wet zone & $88-5089 / \mathrm{Bg} 379-2$ \\
\hline Bw364 & $31 / 2$ & Wet zone & IR 36/Bw 267-3-11M \\
\hline Bw363 & $31 / 2$ & General cultivation & IR 36/BW 267-311M \\
\hline Bw351 & $31 / 2$ & Low country wet zone & Bg 90-2/Bg 401-1 \\
\hline Bw 367 & $31 / 2$ & General cultivation & Bg 358/Bw 361 \\
\hline At353 & $31 / 2$ & Saline prone area & Bg 94-1(R)/Bg400-1//Bg 94-1 \\
\hline At354 & $31 / 2$ & Saline prone area & Bg 94-1/Pokkali \\
\hline At 362 & $31 / 2$ & General cultivation & At $85-2 / \mathrm{Bg} 380$ \\
\hline Ld368 & $31 / 2$ & Wet Zone & Ld 4-9-11/Ld 99-17-4 \\
\hline Ld365 & $31 / 2$ & Wet zone & Selection of Ld 355 \\
\hline $\mathrm{Bg} 380$ & 4 & Dry \&Intermediate zone & $\mathrm{Bg} 90-2 * 4 / \mathrm{Ob} 677$ \\
\hline $\mathrm{Bg} 403$ & 4 & General cultivation & $83-1026 / \mathrm{Bg} 379-2$ \\
\hline $\mathrm{Bg} 406$ & 4 & Northern region & Bg 73-797/Ptb 33/Ob 678 \\
\hline $\mathrm{Bg} 450$ & $41 / 2$ & General cultivation & $\mathrm{Bg} 12-1 * 2 / \mathrm{IR} 42$ \\
\hline $\mathrm{Bg} 454$ & $41 / 2$ & General cultivation & MR 1523/87-519 \\
\hline Bg455 & $41 / 2$ & Submergence areas & Ob2547/CR9413//IR46/Ob 2552 \\
\hline Bg379-2 & $41 / 2$ & Low country wet zone & IR $2071-586 / \mathrm{Bg} 400-1$ \\
\hline Bg 400-1 & 4 & General cultivation & $\mathrm{Ob} 678 / / \mathrm{IR} 20 / \mathrm{H}-4$ \\
\hline Bg11-11 & $41 / 2$ & General cultivation & Engkatek $/{ }^{\# 2} \mathrm{H}-8$ \\
\hline Bw400 & 4 & Saline and acid soils & Bw 259-3/Bw 242-5-5 \\
\hline Bw451 & $41 / 2$ & Low country wet zone & Bg 400-1/Bg 11-11 \\
\hline Bw452 & $41 / 2$ & General cultivation & Hondarawala 502/C 104 \\
\hline Bw453 & $41 / 2$ & Low country wet zone & IR 2071-586/Bg 400-1 \\
\hline At401 & 4 & Costal Saline area & Bg 94-1/Pokkali \\
\hline At402 & 4 & Southern province & $\begin{array}{l}\text { IR4432-52-6-4/Bg90-2//76- } \\
\text { 3990/Ob } 678\end{array}$ \\
\hline
\end{tabular}


Table 1. cont..

\begin{tabular}{|c|c|c|c|}
\hline At 405 & 4 & $\begin{array}{l}\text { Dry and Intermediate } \\
\text { zones }\end{array}$ & At 402/Basmathi 442 \\
\hline Ld408 & 4 & General cultivation & At $01 / \mathrm{Ld} 98-152$ \\
\hline \multicolumn{4}{|c|}{ Old Improved Varieties } \\
\hline $\mathrm{H} 4$ & $41 / 2$ & General cultivation & Murungakayan 302/Mas \\
\hline $\mathrm{H} 7$ & $31 / 2$ & General cultivation & Pachchapefumal/Mas//H-5 \\
\hline $\mathrm{H} 10$ & 3 & General cultivation & Pachchaperumal/Mas/H-5 \\
\hline
\end{tabular}

\section{Plant trait measurements}

Physiological traits of varieties were assessed by evaluating multiple plant attributes closely related to $\mathrm{P}$ deficiency. Three plants were harvested as replicates from each pot at 52 days after planting. Number of tillers, roots and shoot dry weight, and shoot $\mathrm{P}$ content were taken at the time of harvesting.

\section{Phosphorus analyses}

Shoots and roots were air dried for two days and oven dried for 48 hours at $60^{\circ} \mathrm{C}$. Weight of shoots and roots were measured and $5 \mathrm{~g}$ of each sample was ground and made into ash at $200{ }^{\circ} \mathrm{C}$ for $2 \mathrm{~h}$ followed by $450{ }^{\circ} \mathrm{C}$ for $2 \mathrm{~h}$. The ash was dissolved in $6 \% \mathrm{HNO}_{3}$ and $\mathrm{P}$ concentrations were measured by colorimetric assay using the molybdovanadophosphate method using a spectrophotometer (Kitson and Melon, 1944). Shoot P content (SPC) was calculated by multiplying shoot $\mathrm{P}$ concentration with shoot dry weight.

\section{Data analysis}

Measured and calculated data were analyzed using GLM procedure in SAS to determine the main effects of variety, $\mathrm{P}$ concentration and interactions among them. Means were compared using least significant differences at $P=0 \cdot 05$. All the variables of $\mathrm{P}$ deprived condition were subjected to hierarchical cluster analysis using MINITAB statistical software to observe the grouping of varieties.

\section{RESULTS AND DISCUSSION}

The effects of $\mathrm{P}$ concentration in the medium, variety and their interaction on shoot dry weight, root dry weight and total dry weight were significant $(\mathrm{P}<0.05)$. At $50 \mu \mathrm{M} \mathrm{P}$ level shoot and root dry weight among varieties were similar whereas at $10 \mu \mathrm{M}$ P level, dry weights were significantly different among varieties. Therefore, shoot, root and total dry weights were compared separately at $10 \mu \mathrm{M}$ P level for all the varieties tested. Bg 94-1 showed the highest biomass gain in all three aspects. Similarly P content was compared among all the varieties studied. Bg 94-1 showed a higher amount of shoot $\mathrm{P}$ content proving its ability to perform in low P availability. Simultaneously, At 402 has the lowest biomass gain in shoot, root and total dry weights. Low shoot $\mathrm{P}$ content recorded in At 402 confirms the poor performance in $\mathrm{P}$ uptake and utilization efficiency(Figure 2). 
(a)

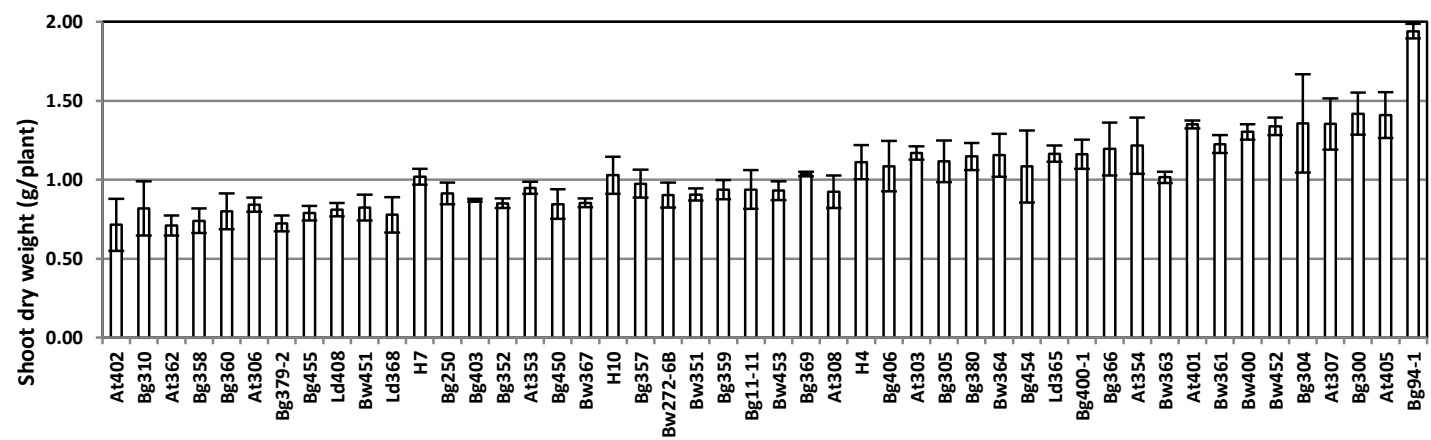

(b)
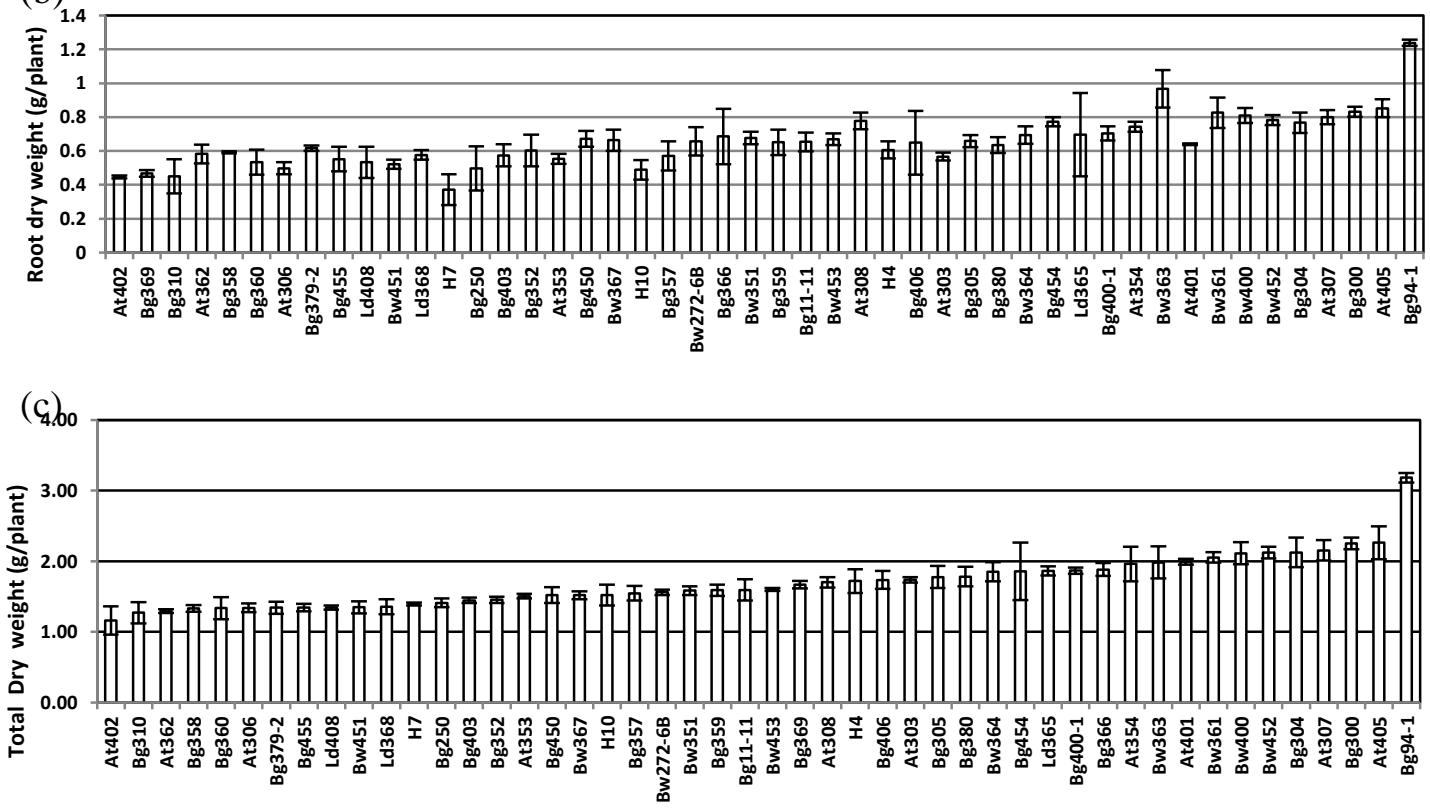

(d)

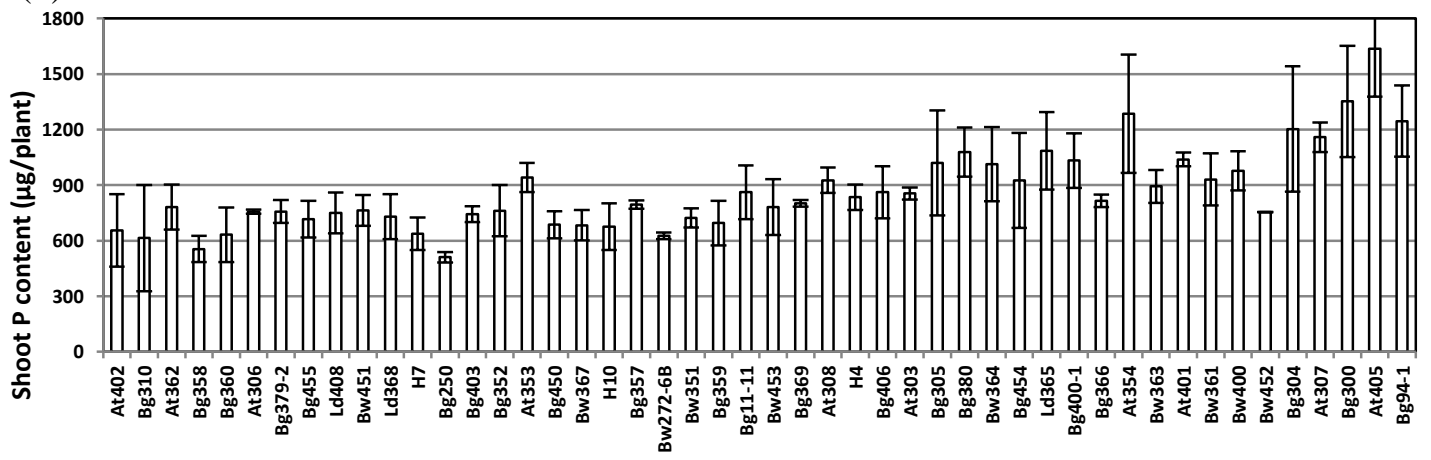

Figure 1. Variation of mean (a) shoot dry weight, (b) root dry weight (c) total dry weight and (d) shoot $P$ content among the varieties grown at low $P$ condition $(10 \mu \mathrm{M})$ Grouping of varieties 
Crop varieties can be classified in to two different groups according to their responses to nutrient supply such as efficient or inefficient in nutrient deficient condition and responder or non- responder in nutrient sufficient condition (Ortiz-Monasterio et al., 2001). The dendrogram drawn using shoot and root dry weights, shoot $\mathrm{P}$ concentrations and contents and number of tillers under low $\mathrm{P}$ condition at 52 days after planting showed two distinct clusters. The varieties At405, Bg94-1, At307, Bg304, Bg300 and At354 clustered in to Cluster 2 while all other 44 varieties clustered in to Cluster 1 at similarity level at 33\% (Figure 2). Varieties belonging to each cluster are shown in Table 2 and the means of each parameter are shown in Table 3. Means of all the P efficiency related parameters of Cluster 2 are greater than those of Cluster 1 revealing that the varieties in Cluster 2 are tolerant to P deficiency. Bg94-1, Bg304, At405 and At354 varieties have previously been identified as early tillering varieties at low P available condition confirming their efficiency for $\mathrm{P}$ uptake and use (Kekulandara et al, 2016). Although varieties At354 and $\mathrm{Bg} 300$ included in phosphorus deficiency tolerant category in this study, they were grouped under susceptible group by Aluvihare et al. (2016). Similarly, At362 was identified as P deficiency tolerant variety by Aluvihare et al. (2016) while an opposite response was observed in the present experiment. Bg 94-1 has been identified as a tolerant variety in both the studies. Each cluster consists of short, medium and long age rice varieties. It indicates that clustering has been made irrespective of the maturity age of the variety proving that there is no effect of the age of the variety on $\mathrm{P}$ deficiency tolerance.

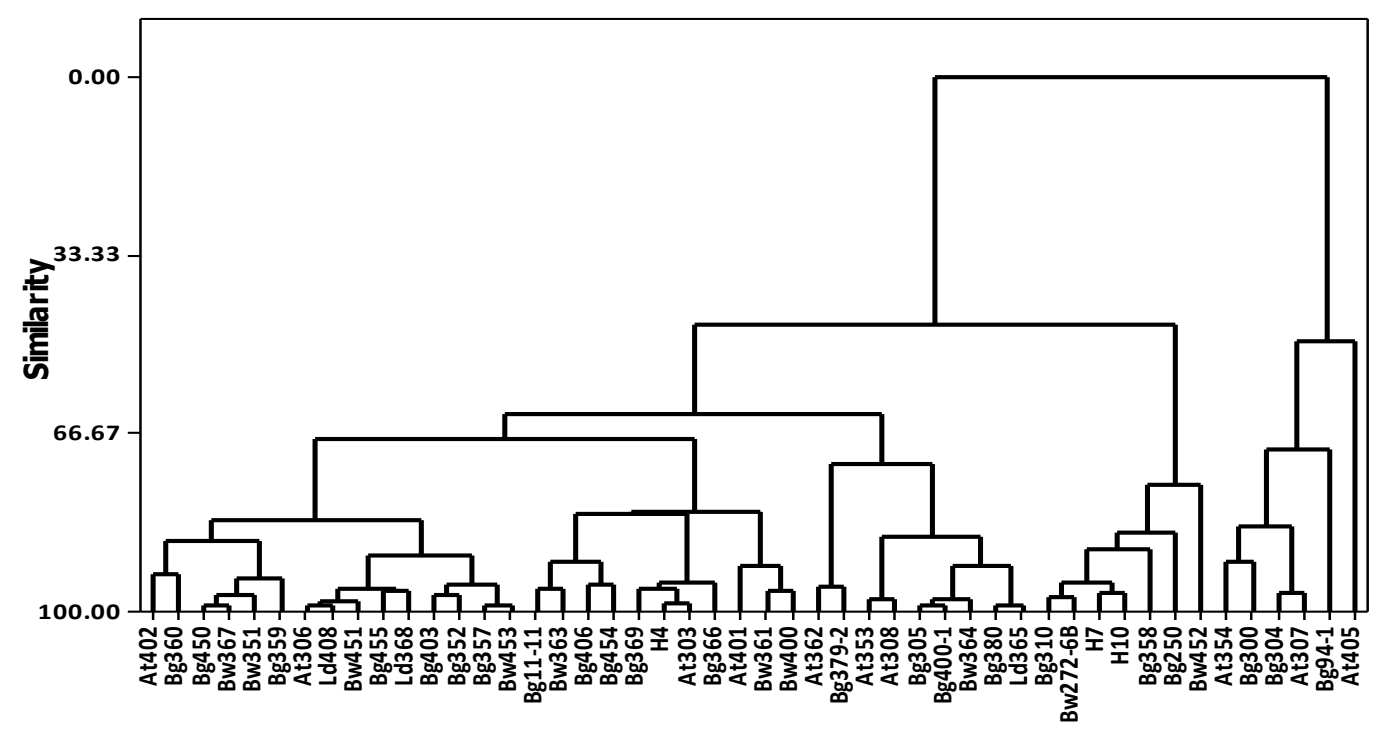

Figure 2. Dendrogram constructed by using shoot and root dry weights, number of tillers and shoot $P$ concentration and contents at $10 \mu \mathrm{M} P$ supply 
Table 2. Varieties in different clusters

\begin{tabular}{|c|c|c|c|c|}
\hline \multicolumn{3}{|c|}{ Cluster 1} & \multicolumn{2}{|r|}{ Cluster2 } \\
\hline At 303 & At308 & At306 & $\mathrm{Bg} 403$ & At354 \\
\hline Bw400 & At353 & $\mathrm{Bg} 455$ & Bw451 & Bg94-1 \\
\hline At401 & Bg400-1 & Bw351 & $\mathrm{Bg} 359$ & $\mathrm{Bg} 300$ \\
\hline Bw364 & Ld365 & $\mathrm{Bg} 352$ & H10 & At405 \\
\hline $\mathrm{Bg} 380$ & $\mathrm{Bg} 454$ & Ld408 & $\mathrm{Bg} 250$ & A307 \\
\hline $\mathrm{Bg} 360$ & Bw361 & $\mathrm{Bg} 450$ & $\mathrm{Bg} 358$ & Bg304 \\
\hline $\mathrm{Bg} 406$ & At362 & $\mathrm{Bg} 310$ & $\mathrm{Bg} 369$ & \\
\hline $\mathrm{H} 4$ & Bg379-2 & $\mathrm{H} 7$ & Bg366 & \\
\hline Bw363 & Bg272-6B & At402 & & \\
\hline Bw452 & Bg11-11 & Bw367 & & \\
\hline Bw453 & $\mathrm{Bg} 305$ & $\mathrm{Bg} 357$ & & \\
\hline Ld368 & & & & \\
\hline
\end{tabular}

Table 3. Mean values of variables in each cluster

\begin{tabular}{lll}
\hline & Cluster 1 & Cluster 2 \\
\hline Shoot dry weight (g/plant) & $0.97 \pm 0.08$ & $1.45 \pm 0.16$ \\
Root dry weight (g/plant) & $0.63 \pm 0.05$ & $0.87 \pm 0.09$ \\
Total dry weight $(\mathrm{g} /$ plant $)$ & $1.60 \pm 0.10$ & $2.32 \pm 0.16$ \\
Shoot P concentration $(\mu \mathrm{g} / \mathrm{g})$ & $825.7 \pm 78.9$ & $918.8 \pm 113.3$ \\
Shoot P content $(\mu \mathrm{g} /$ plant $)$ & $801.8 \pm 103.5$ & $1313.3 \pm 248.2$ \\
Number of tillers per plant & $1.71 \pm 0.20$ & $2.44 \pm 0.33$ \\
\hline
\end{tabular}

\section{Regression analysis}

Scatter plot drawn for total dry weight of varieties against their time taken for matutity under low P conditions is shown in Figure 3. It descriminates Bg300, Bg94-1, At405 and Bw452 producing greater biomass from the age groups of 3 month, $3 \frac{1}{2} 2$ month, 4 month and $4 \frac{1}{2}$ month age groups respectively at low $\mathrm{P}$ supplied environment. Scatter plot drawn against maturity age and the mean P content in shoots is shown in Figure 4. Varieties Bg300, At354, At 405 and $\mathrm{Bg} 380$ were the superior in 3 month, $3 \frac{1}{2} 2$ month, 4 month and $4 \frac{1}{2}$ month age groups, rspectively. 


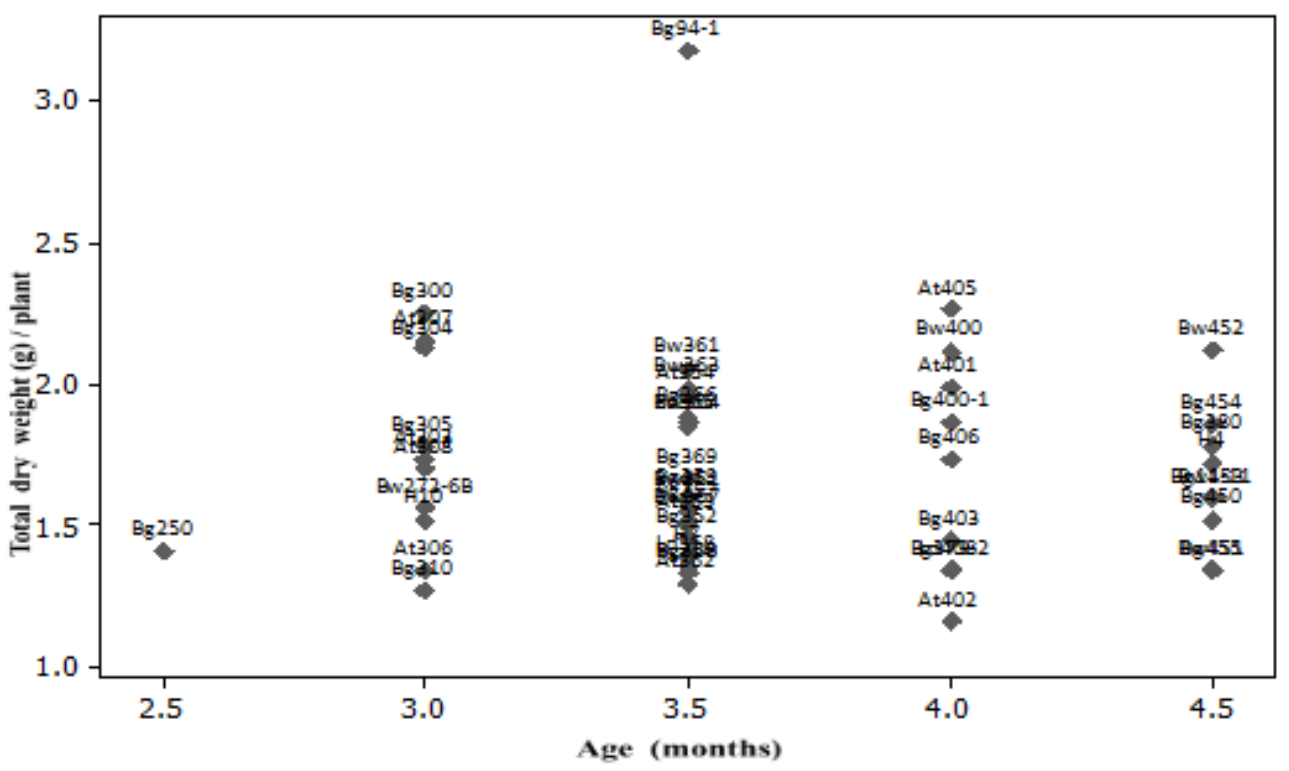

Figure 3. Distribution of varieties based on total dry weight gained at low $P$ availability according to their maturity age classes

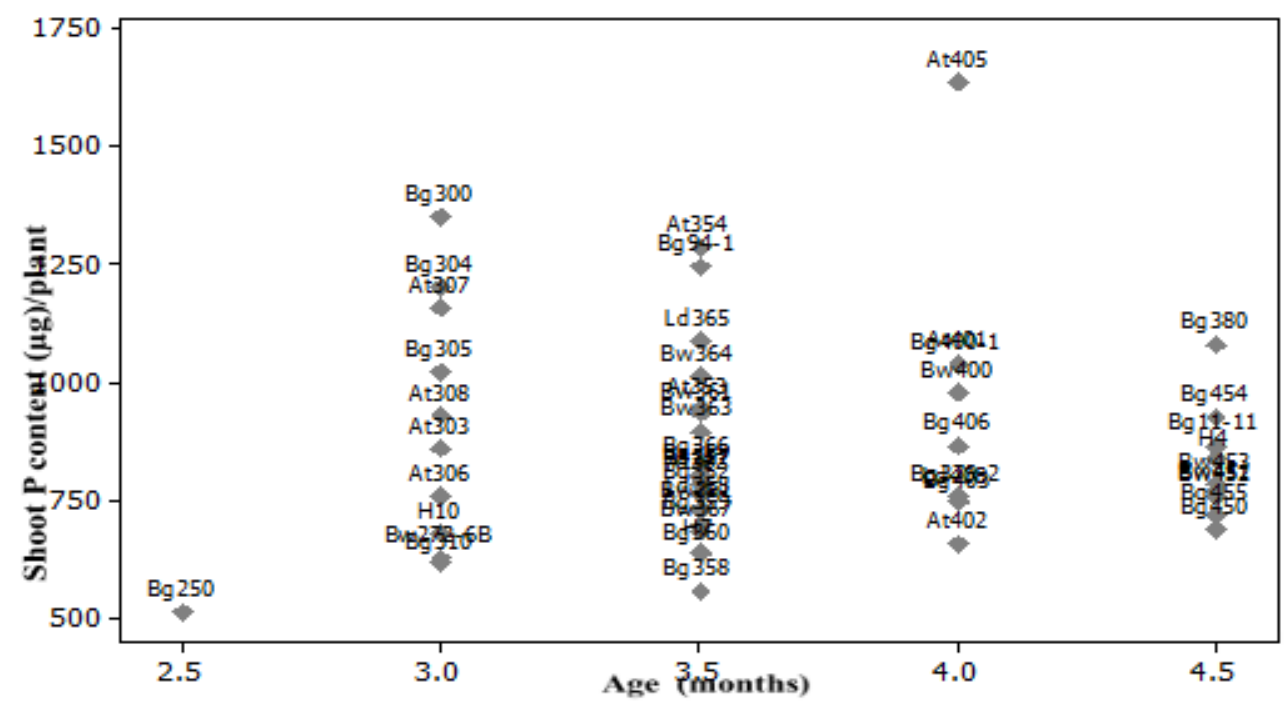

Figure 4. Distribution of varieties based on shoot $P$ content at low $P$ availability against their maturity age classes 


\section{Comparison of varietal performance under high and low $P$ availability}

The scatter plot drawn for biomass gained at low $\mathrm{P}$ and high $\mathrm{P}$ availability illustrates that varieties Bg94-1, At405, Bg300, Bg304 and At307 performed well in both at low and high P availability, whereas $\mathrm{H} 7, \mathrm{H} 4, \mathrm{Bg} 455$, At306, At402 and $\mathrm{Bg} 11 / 11$ performed poorly in both conditions (Figure 6). However, some varieties such as Bg250, Bg358, Bg310 and Bg369 have gained comparatively higher dry weight in high $\mathrm{P}$ availability compared to $\mathrm{P}$ deprived condition. Most of the short age varieties have shown higher dry weight at 52 days after planting at high $\mathrm{P}$ supply. It is clear that dry weight of all the varieties has reduced by more than half at low $\mathrm{P}$ condition compared to high $\mathrm{P}$ supply confirming the importance of $\mathrm{P}$ in plant growth and the occurrence of $\mathrm{P}$ deficiency at $10 \mu \mathrm{M}$ P supply (Figure 5).

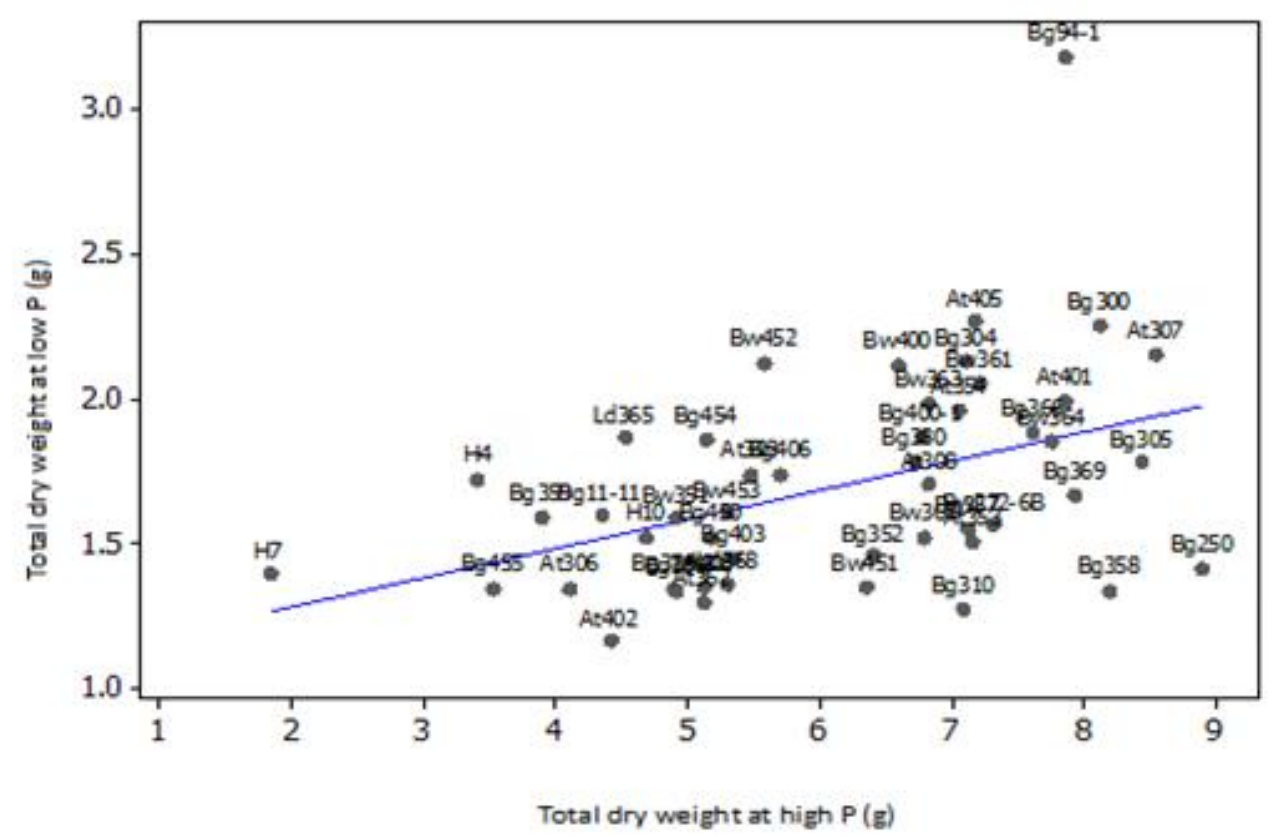

Figure 5. Varietal performances on dry weight gained at low $P$ vs high $P$ availability at 52 days after planting.

Efficient genotypes possess high $\mathrm{P}$ uptake efficiency, whereas responders show high utilization efficiency. As nutrient uptake and utilization processes are interdependent from each other, it is difficult to distinguish a responder from an efficient cultivar. Therefore, efficient screening method is important to select cultivars for low-nutrient tolerance (Agrama, 2006). Deficiency symptoms of plants can be studied well using hydroponics, where the presence or absence of nutrient components can be controlled precisely. Studies under controlled conditions in a hydroponic solution generally involve giving precise $\mathrm{P}$ deficiency stress on seedlings over in the field which may show a considerable level of spatial and temporal variation in P content in the medium. In addition, it makes easier to observe deficiency symptoms that occur in the roots, which is difficult to observe in soil-grown plants (Salisbury and Ross, 1992). Thus, hydroponic based screening system gives more reliable data than nutrient experiments conducted in soil although it is not the real practice adopted in rice cultivation. 


\section{CONCLUSIONS}

There is a significant variation in genotypes for $\mathrm{P}$ deficiency tolerance in rice. The $\mathrm{P}$ deficiency tolerance ability in varieties did not show any correlation with their maturity age classes. $\mathrm{Bg} 300, \mathrm{Bg} 304$ and At307 in 3 month age group, Bg94-1, At354 in 31/2 month age group and At405 in 4 month age group performed well in both $\mathrm{P}$ uptake and dry matter production. Bg941 performed extraordinarily in biomass gain and $\mathrm{P}$ accumulation. Simultaneously, At 402 showed poor performance in biomass gain in both shoots and roots. Low amount of shoot $\mathrm{P}$ content recorded in At402 confirms its poor $\mathrm{P}$ uptake and utilization efficiency under $\mathrm{P}$ deprived conditions.

\section{ACKNOLEDGEMENT}

This work was supported by a grant from the National Science Foundation, Sri Lanka (NSF/AG/2014/01|). We thank the Director, Rice Research and Development Institute for providing seed materials for this research. We are very much grateful to all the staff members of Agricultural Biotechnology Center $(\mathrm{AgBC})$ for providing facilities and fullest support for conducting research at $\mathrm{AgBC}$ and Mr. Gemunu Wijesuriya at the Department of Crop Science, University of Peradeniya for technical assistance.

\section{REFERENCES}

Agrama, H. A. (2006). Application of molecular markers in breeding for nitrogen use efficiency. Journal of Crop Improvement. 15, 175-211.

Aluwihare, Y.C., Ishan, M. , Chamikara, M.D.M., Weebedde, C. K, Sirisena, D. N., Samarasinghe, W. L. G., Sooriyapathirana, S. D. S. S.(2016). Characterization and selection of phosphorus deficiency tolerant rice genotypes in Sri Lanka. Rice Science. 23, 184-195.

Dawe, D. (2000). The potential role of biological nitrogen fixation in meeting future demand for rice and fertilizer. In: Ladha JK, Reddy PM, editors. The quest for nitrogen fixation in rice. Philippines: International Rice Research Institute. 1-9.

De Datta,S.K. (1981) Principles and practice of rice production. Singapore: John Wiley and Sons. 348-419.

Dobermann, A., Fairhurst, T. (2000). Rice: nutrient disorders \& nutrient management. Potash \& Phosphate Institute, Potash \& Phosphate Institute of Canada and International Rice Research Institute Singapore and Los Baños.

Fageria, N. K, Wright, R. J., Baligar, R.C., (1998). Cultivar evaluation for phosphorus use efficiency. Plant and Soil 111, 105-109.

Kekulandara, D.S., Suriyagoda, L.D.B., Bandaranayake, P.C.G., Sirisena, D.N. and Samarasinghe, W.L.G. (2016). Temporal tillering behavior of Sri Lankan elite rice varieties in response to phosphorus availability. Tropical Agricultural Research.28 (2), 133 - 143. 
Khush, G. S. (1995) Modern varieties - their real contribution to food supply and equity.Geojournal. 35 (3), 275 - 284.

Kitson, R.E., Melon, M.G. (1944). Colorimetric determination of phosphorus as molybdovanadophosphoric acid. IndEngChem Anal Ed 16:379.

Kottearachchi, N.S. and Wijesekara, U.A.D.S.L. (2013). Implementation of Pup 1 gene based markers for screening of donor varieties for phosphorus deficiency tolerance in rice. Indian Journal of Plant Sciences.2 (4), 76-83.

Ortiz-Monasterio, J.I., Manske, G.G.B., van Ginkel, M. (2001). Nitrogen and phosphorus use efficiency. In: Reynolds MP, Ortiz-Monasterio JI, McNab A, eds. Application of physiology in wheat breeding. Mexico: CIMMYT, 200-207.

Redfern, S.K., Azzu, N., Binamira, J.S. (2012). Rice in Southeast Asia: facing risks and vulnerabilities to respond to climate change. Building resilience for adaptation to climate change in the agriculture sector. 23, 295-314.

Rose, T.J., Wissuwa, M. (2012) Rethinking internal phosphorus utilization efficiency: a new approach is needed to improve PUE in grain crops. Adv. Agron. 116,183-215

Salisbury, F. B. and Ross,C.W. (1992). Plant Physiology, 4th ed. Wadsworth Publishing Co., Belmont, CA.

Sanchez, P. A. and Salinas, J. G. (1981) Low input technology for managing oxisols and ultisols in tropical America. Adv. Agron. 34, 279-398.

Sirisena, D. N. and Suriyagoda, L.D.B. (2018). Towards sustainable phosphorus management in Sri Lankan rice and vegetable-based cropping systems. Agriculture and Natural Resources. $52,9-15$.

Tirado, R. \& Allsopp, M.(2012). Phosphorus in agriculture: Problems and solutions.

Vinod , K.K. and Heuer, S. (2012). Approaches towards nitrogen- and phosphorus-efficient rice. AoB Plants, pls028. [PubMed].

Yoshida, S, Forno, D.A.,Cock, J.H., Gmez, K.A. (1976). Laboratory manual for physiological studies of rice, IRRI.

Yost, R. S., Kamprath, E. J., Lobato, E. and Naderman, G. C. (1979). Phosphorus response of corn on an oxisol as influenced by rates and placement. Soil Sci. Soc. Am. J. 43, 338-343. 